\title{
Rhamnose Binding Protein as an Anti-Bacterial Agent-Targeting Biofilm of Pseudomonas aeruginosa
}

\author{
Tse-Kai Fu ${ }^{1,2}$, Sim-Kun Ng ${ }^{1}$, Yi-En Chen ${ }^{1}$, Yuan-Chuan Lee ${ }^{1,3}$, Fruzsina Demeter ${ }^{4}$, \\ Mihály Herczeg ${ }^{4}{ }^{(D}$, Anikó Borbás ${ }^{4}$, Cheng-Hsun Chiu ${ }^{5}$, Chung-Yu Lan ${ }^{1,5}{ }^{(0)}$, Chyi-Liang Chen ${ }^{6}$ \\ and Margaret Dah-Tsyr Chang ${ }^{1,5, *}$ \\ 1 Institute of Molecular and Cellular Biology, National Tsing Hua University, Hsinchu 30013, Taiwan; \\ gn00042366@gmail.com (T.-K.F.); flyingsim02@hotmail.com (S.-K.N.); ian8004@gmail.com (Y.-E.C.); \\ yclee@jhu.edu (Y.-C.L.); cylan@life.nthu.edu.tw (C.-Y.L.) \\ 2 Simpson Biotech Co., Ltd., Taoyuan 333, Taiwan \\ 3 Department of Biology, Johns Hopkins University, Baltimore, ML 21218, USA \\ 4 Department of Pharmaceutical Chemistry, University of Debrecen, Debrecen 4032, Hungary \\ demeter.fruzsina@science.unideb.hu (F.D.); herczeg.mihaly@science.unideb.hu (M.H.); \\ borbas.aniko@pharm.unideb.hu (A.B.) \\ 5 Department of Life Science, National Tsing Hua University, Hsinchu 30013, Taiwan; \\ chchiu@adm.cgmh.org.tw \\ 6 Molecular Infectious Disease Research Center, Chang Gung Memorial Hospital, Chang Gung University \\ College of Medicine, Taoyuan 333, Taiwan; dinoschen@adm.cgmh.org.tw \\ * Correspondence: dtchang@life.nthu.edu.tw; Tel.: +886-3-574-2767
}

Received: 24 May 2019; Accepted: 12 June 2019; Published: 14 June 2019

\begin{abstract}
More than $80 \%$ of infectious bacteria form biofilm, which is a bacterial cell community surrounded by secreted polysaccharides, proteins and glycolipids. Such bacterial superstructure increases resistance to antimicrobials and host defenses. Thus, to control these biofilm-forming pathogenic bacteria requires antimicrobial agents with novel mechanisms or properties. Pseudomonas aeruginosa, a Gram-negative opportunistic nosocomial pathogen, is a model strain to study biofilm development and correlation between biofilm formation and infection. In this study, a recombinant hemolymph plasma lectin ( $\mathrm{rHPL} \mathrm{OE}_{\mathrm{E}}$ ) cloned from Taiwanese Tachypleus tridentatus was expressed in an Escherichia coli system. This $\mathrm{rHPL}_{\mathrm{OE}}$ was shown to have the following properties: (1) Binding to P. aeruginosa PA14 biofilm through a unique molecular interaction with rhamnose-containing moieties on bacteria, leading to reduction of extracellular di-rhamnolipid (a biofilm regulator); (2) decreasing downstream quorum sensing factors, and inhibiting biofilm formation; (3) dispersing the mature biofilm of P. aeruginosa PA14 to improve the efficacies of antibiotics; (4) reducing P. aeruginosa PA14 cytotoxicity to human lung epithelial cells in vitro and (5) inhibiting P. aeruginosa PA14 infection of zebrafish embryos in vivo. Taken together, $\mathrm{rHPL}_{\mathrm{OE}}$ serves as an anti-biofilm agent with a novel mechanism of recognizing rhamnose moieties in lipopolysaccharides, di-rhamnolipid and structural polysaccharides (Psl) in biofilms. Thus rHPL $_{\mathrm{OE}}$ links glycan-recognition to novel anti-biofilm strategies against pathogenic bacteria.
\end{abstract}

Keywords: rhamnose-binding protein; anti-biofilm; quorum sensing factor; anti-infection

\section{Introduction}

Part of the reasons for bacterial resistance to antibiotics are due to the formation of biofilm, composed of secreted polysaccharides, proteins, glycolipids and small molecules in the bacterial microenvironment. Recent development of antimicrobial agents with novel molecular mechanisms to control bacterial infectious diseases has drawn much attention [1]. The inhibition of bacterial biofilm 
formation by non-microbicidal mechanisms is an example of anti-pathogenic approaches [2,3]. One nosocomial infectious bacteria, Pseudomonas aeruginosa, is responsible for various infections, particularly in immuno-compromised individuals [4], and it forms biofilms to make antibiotic treatments inefficient and therefore promotes acute infections, for example, at upper airway, skin, wound, urinary tract, enteric and lung [5]. P. aeruginosa PA14 is a clinically isolated and highly virulent strain representing the most common clonal group worldwide [6]. The PA14 genome showing a high degree of conservation compared to that of the P. aeruginosa strain PAO1 contains two specific pathogenicity islands. The PA14 islands carried several genes implicated in virulence that are absent in PAO1, including genes encoding effectors of the type III secretion system for secreting virulent factors $[7,8]$. These characteristics make PA14 a threat to public health, but a good model for P. aeruginosa infection studies.

Biofilm development is associated with changes in bacteria phenotype and metabolic pathways [9]. During biofilm development, physiological changes of bacterial cells are regulated by a chemical signaling mechanism involving cell-to-cell communication, such as quorum-sensing (QS) signaling. The process of $P$. aeruginosa biofilm development is mainly regulated by three interconnected QS systems: Two use acyl-L-homoserine lactones (AHLs) and the third uses aquinolone [10]. In the AHL QS system, LasI-synthase generates N-(3-oxododecanoyl)-L-homoserine lactone [11] and RhII synthase generates $\mathrm{N}$-butyryl-L-homoserine lactone [12]. The former is a key factor in the maturation stage of the biofilm [13], and the latter is responsible for production of another biofilm regulator, di-rhamnolipid [14]. Numerous molecules with anti-QS property have been reported to inhibit biofilm formation of $P$. aeruginosa [15]. AHL analogues have inhibitory activities on biofilm formation in P. aeruginosa by down-regulating LasR-based QS system (LasR, a transcriptional regulator response for AHL). Some modified AHL analogues can also down-regulate pyocyanin, a virulence factor with elastase activity [16]. Certain enzymes are secreted by mammalian cells such as paraoxonases, which lactonase activity can degrade P. aeruginosa AHLs and further inhibit QS and biofilm formation. Most of these AHL pathway inhibitors efficiently work under $10 \mu \mathrm{M}$.

There already exist many different anti-biofilm agents from various resources. For example, cultured broth from certain marine cold adapted bacteria destabilized biofilm of Pseudomonas aeruginosa [17] and some essential oils from Mediterranean plants or selected exopolysaccharide from marine bacteria acts as anti-QS factors to inhibit biofilm formation of Pseudomonas aeruginosa $[18,19]$. Although AHL pathway inhibitors already exist, they still cannot completely inhibit the biofilm produced by P. aeruginosa [15], indicating that biofilm development is not only controlled by the AHL pathway but also other pathways that might partially complement to develop biofilm. This hypothesis leads us to focus on factors that may directly regulate biofilm development. Di-rhamnolipid, as a glycolipid secreted by P. aeruginosa, has been implicated in each of the following phases of biofilm development: (i) Forming microcolonies [20], (ii) regulating both cell-to-cell and cell-to-surface interactions [21], (iii) creating and maintaining fluid channels for water and oxygen flow around the base of the biofilm [21] and (iv) facilitating 3-D mushroom-shaped structure formation [22]. Accordingly, di-rhamnolipid seems to be a regulator that might directly interact with biofilms. The influence of di-rhamnolipid to biofilm development was observed, but the interaction of di-rhamnolipid with other QS factors remains unclear. To develop anti-biofilm reagents directly targeting di-rhamnolipid might be a novel anti-biofilm approach.

Rhamnose binding proteins (RBPs) are mainly isolated from eggs, ovary cells of fish and invertebrates with L-rhamnose (Rha) or D-galactose binding specificities [23,24]. RBPs are typically located in immune-related tissues or cells [25], suggesting that RBPs may be relevant to self-defense mechanisms. RBPs may interact and agglutinate Gram-negative and Gram-positive bacteria by recognizing lipopolysaccharide (LPS) and lipoteichoic acid (LTA), respectively [26]. RBPs can recognize some $\mathrm{O}$-antigens and bind to glycolipids and glycoproteins of fish pathogens [27]. The RBP receptor is expressed on peritoneal macrophages of fish after an inflammatory stimulation [28]. The tissue specificity of expression and ability to interact with bacteria indicates that RBPs are naturally related to the innate immune system in animals as a pathogen recognition element. 
An RBP possessing specific binding of L-rhamnose was discovered from horseshoe crab plasma and recently engineered for expression in the Escherichia coli system [29]. This recombinant horseshoe crab plasma lectin (rHPL) possesses a very low sequence identity with known RBPs and does not have conserved domains. Interestingly, rHPL binds to bacteria or pathogen-associated molecular patterns (PAMPs) by recognizing rhamnose moieties and inhibits the growth of P. aeruginosa [29]. Unlike other RBLs, rHPL only binds to L-rhamnose and rhamnobiose but not to galactose or mannose [30]. This high substrate specificity makes rHPL a prospective candidate to bind rhamnose-containing components in biofilm of $P$. aeruginosa and examine the biological functions of these bindings.

\section{Results}

\section{1. $r H P L_{O E}$ Was Expressed in E. coli and Purified by Affinity Chromatography}

rHPL was successfully expressed in E. coli in 2014. The yield of rHPL purified using a nickel-affinity column was $\sim 8 \mathrm{mg} / \mathrm{L}$, and the purity was $93 \%$ [29]. To improve the productivity and solubility of rHPL, the codon usage of synthetic $h p l$ (hploe) was optimized for E. coli, and recombinant HPL $\mathrm{OE}$ was co-expressed with chaperones. The expression product, $\mathrm{rHPL}_{\mathrm{OE}}$, was purified by fast protein liquid chromatography (FPLC) equipped with a HisTrap ${ }^{\mathrm{TM}}$ affinity column following purification scheme in supplementary data showed in Table S1. rHPL ${ }_{D M}$, representing rHPL with two artificial mutations Y88A and F145A, which showed no binding activities to a bacterial cell- (Figure S1A) or pathogen-associated molecular pattern (PAMP; Figure S1B), was applied as a negative control in this study. Figure S2 illustrated the purification chromatogram and SDS polyacrylamide gel electrophoresis analysis data. The purified $\mathrm{rHPL}_{\mathrm{OE}}$ was desalted and concentrated using an Amicon protein concentrator (10 kDa cut-off) and subjected to further analysis. Figure S3 showed the secondary structure of $\mathrm{rHPL}_{\mathrm{OE}}$ determined by circular dichroism (CD) spectroscopy in comparison to those of rHPL and $\mathrm{rHPL}_{\mathrm{DM}}$, indicating that both $\mathrm{rHPL}_{\mathrm{OE}}$ and $\mathrm{rHPL}_{\mathrm{DM}}$ possessed similar structures to rHPL [29]. A yield of $11.33 \mathrm{mg} / \mathrm{L} \mathrm{rHPL}_{\mathrm{OE}}$ with a comparable purity. The yield of $\mathrm{rHPL}_{\mathrm{OE}}$ was 1.4-fold higher than that of rHPL, suggesting that the chaperone improved the solubility and stability of rHPL in the $E$. coli system.

\section{2. $r H P L_{O E}$ Bound to Cell-Free Biofilm Matrix from P. aeruginosa PA14 via Recognizing Rhamnose}

Our hypothesis is that $\mathrm{rHPL}_{\mathrm{OE}}$ might bind to rhamnose-containing components in the biofilm and further interrupt bacterial biofilm development. First, binding capacity of rHPL $\mathrm{OE}_{\mathrm{OE}}$ to the cell-free biofilm matrix from P. aeruginosa PA14 was tested. Here, a mature P. aeruginosa PA14 biofilm was extracted using a $\mathrm{NaCl}$ solution to give a cell-free biofilm matrix. In the extracted PA14 biofilm, the total protein was $0.19 \mathrm{mg} / \mathrm{mL}$ and polysaccharide, $0.32 \mathrm{mg} / \mathrm{mL}$. Di-rhamnolipid, an important QS-factor and putative binding target of $\mathrm{rHPL}_{\mathrm{OE}}$, was extracted using chloroform, and was $0.66 \mu \mathrm{g} / \mathrm{mL}$ by methylene blue method. The interaction between $\mathrm{rHPL}_{\mathrm{OE}}$ and the cell-free biofilm matrix was measured by ELISA, and the inhibitory effect of monosaccharides and alginate on $\mathrm{HHPL}_{\mathrm{OE}}$-biofilm interaction was determined using competitive ELISA. rHPL $\mathrm{OE}_{\mathrm{E}}$ at a final concentration of $0.1 \mu \mathrm{M}$ was mixed with L-rhamnose and loaded into microplate wells coated separately with extracted P. aeruginosa PA14 biofilm. rHPL $\mathrm{OE}_{\mathrm{O}}$ mixed with buffer only was used as a positive control. rHPL $\mathrm{DM}_{\mathrm{DM}}$ without rhamnose binding activity served as a negative control. As shown in Figure 1, addition of 25, 50, and $100 \mathrm{mM}$ of L-rhamnose effectively reduced binding of $\mathrm{rHPL}_{\mathrm{OE}}$ to the extracted biofilm, in comparison with the positive control. The inhibitory constant $\left(K_{i}\right)$ of L-rhamnose to $\mathrm{rHPL}_{\mathrm{OE}}$ interaction with the biofilm of P. aeruginosa PA14 was $98 \mathrm{mM}$. The addition of $100 \mathrm{Mm}$ of D-mannose, D-glucose, D-fructose, $\mathrm{D}$-galactose and alginate could not reduce the binding between $\mathrm{rHPL}_{\mathrm{OE}}$ and the extracted biofilm. These results indicated that $\mathrm{rHPL}_{\mathrm{OE}}$ specifically bound to rhamnose containing components in P. aeruginosa PA14 biofilm. 


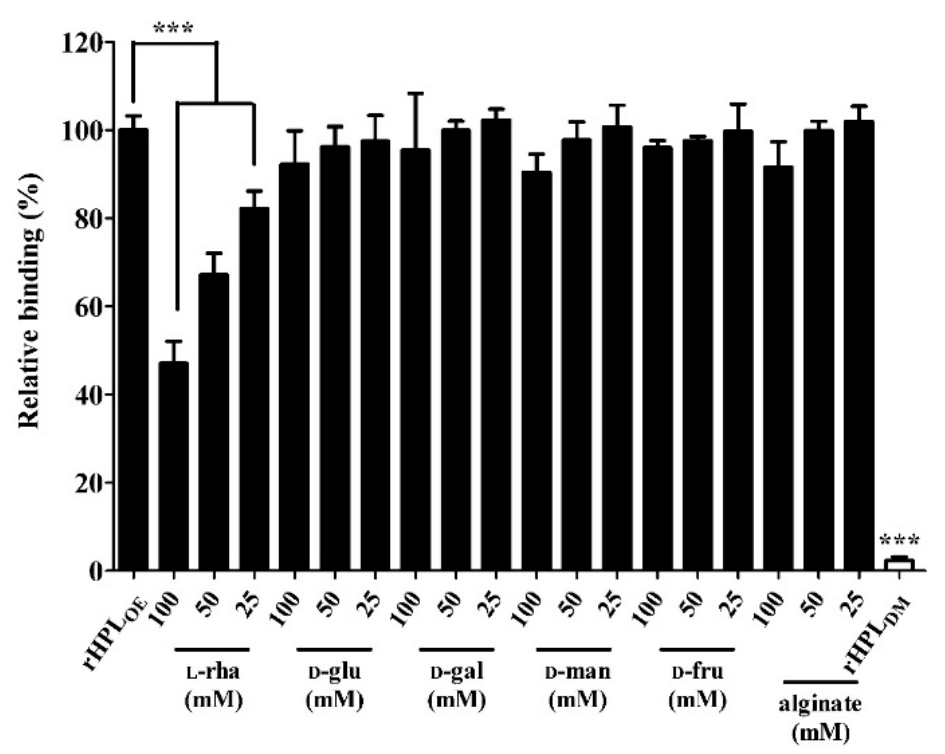

Figure 1. Inhibitory effects of monosaccharides on the recombinant hemolymph plasma lectin (rHPL $\mathrm{OE}_{\mathrm{OE}}$ )-biofilm interaction. The binding activity of $\mathrm{rHPL}_{\mathrm{OE}}$ to the PA14 biofilm and inhibitory effects of monosaccharides or alginate on this binding were determined by competitive ELISA. rHPL $L_{D M}$ was applied as a negative control. ${ }^{* * *} p<0.001$ versus the $\mathrm{rHPL}_{\mathrm{OE}}$ only group (positive control).

\subsection{Synthetic Rhamnobiosides and a Pentasaccharide Inhibited $r H P L_{O E}-$ Biofilm Interaction}

To confirm that binding of rHPL $\mathrm{OE}_{\mathrm{O}}$ to the P. aeruginosa PA14 biofilm was via molecular recognition of rhamnose moiety, synthetic rhamno-oligosaccharides (Figure 2A,B) were used as competitors in a competitive ELISA. The chemical synthesis of phenylthio-rhamnobiosides and the Psl-pentasaccharide will be published elsewhere. The characterization of the new oligosaccharides used in this study is given in the Supplementary Information (Figures S4-S6).

Figure 2 indicated that all synthetic compounds competed with the $\mathrm{rHPL}_{\mathrm{OE}}$-biofilm interaction. The disaccharides are better inhibitor than monosaccharides, and (1-3)-linked rhamnosides were better than its (1-2)-linked counterparts. Psl-pentasaccharide showed the strongest competition presumably due to longer glycan chain length. The competitive effects of rhamnobiosides were stronger than those of rhamnobioses, indicating either a fixed anomeric configuration or hydrophobicity of aglycones slightly favors binding.

\section{4. $r H P L_{O E}$ Bound to Di-Rhamnolipid via Recognizing Rhamnose Portion}

After confirming the binding activity of $\mathrm{rHPL}_{\mathrm{OE}}$ to synthetic rhamnobiosides, direct binding activity of rHPL $\mathrm{OE}$ to di-rhamnolipid from P. aeruginosa PA14 biofilm was measured by ELISA. Further competitive ELISA indicated that rHPL $_{\mathrm{OE}}$ binding to di-rhamnolipid could be competed more effectively by L-rhamnose compared to other monosaccharides (Figure 3).

\section{5. $r H P L_{O E}$ Inhibited Biofilm Formation and Dispersed the Preformed Biofilm of P. aeruginosa PA14}

This experiment was conducted in M63 broth, a minimal low-osmolarity medium to slow down the growth rate of bacteria and mimic nutrient-depleted conditions for biofilm growth [31]. rHPL was applied as a negative control. As shown in Figure 4A, $0.31 \mu \mathrm{M}$ and higher concentrations up to 5 $\mu \mathrm{M}$ of $\mathrm{rHPL}_{\mathrm{OE}}$ significantly inhibited the biofilm formation of P. aeruginosa PA14. Treatment with 0.31 , $0.63,1.25,2.5$ and $5 \mu \mathrm{M}$ rHPL $\mathrm{OE}$ significantly reduced biofilm formation to $49 \%, 51 \%, 39 \%, 18 \%$ and $13 \%$, respectively. As expected, $\mathrm{rHPL}_{\mathrm{DM}}$ did not inhibit biofilm formation. $\mathrm{rHPL}_{\mathrm{OE}}$ was also evaluated for its biofilm dispersion activity with preformed biofilm. The mature biofilm of P. aeruginosa PA14 was dispersed by $16 \%$ and $24 \%$ upon treatment with 2.5 and $5 \mu \mathrm{M} \mathrm{rHPL}_{\mathrm{OE}}$ for $24 \mathrm{~h}$, respectively (Figure $4 \mathrm{~B}$ ). 
However, $\mathrm{rHPL}_{\mathrm{DM}}$ did not disperse the mature biofilm. These results indicated that $\mathrm{rHPL}_{\mathrm{OE}}$ inhibited biofilm formation and dispersed the mature biofilm of P. aeruginosa PA14 and that both activities perhaps are correlated with the rhamnose binding activity.
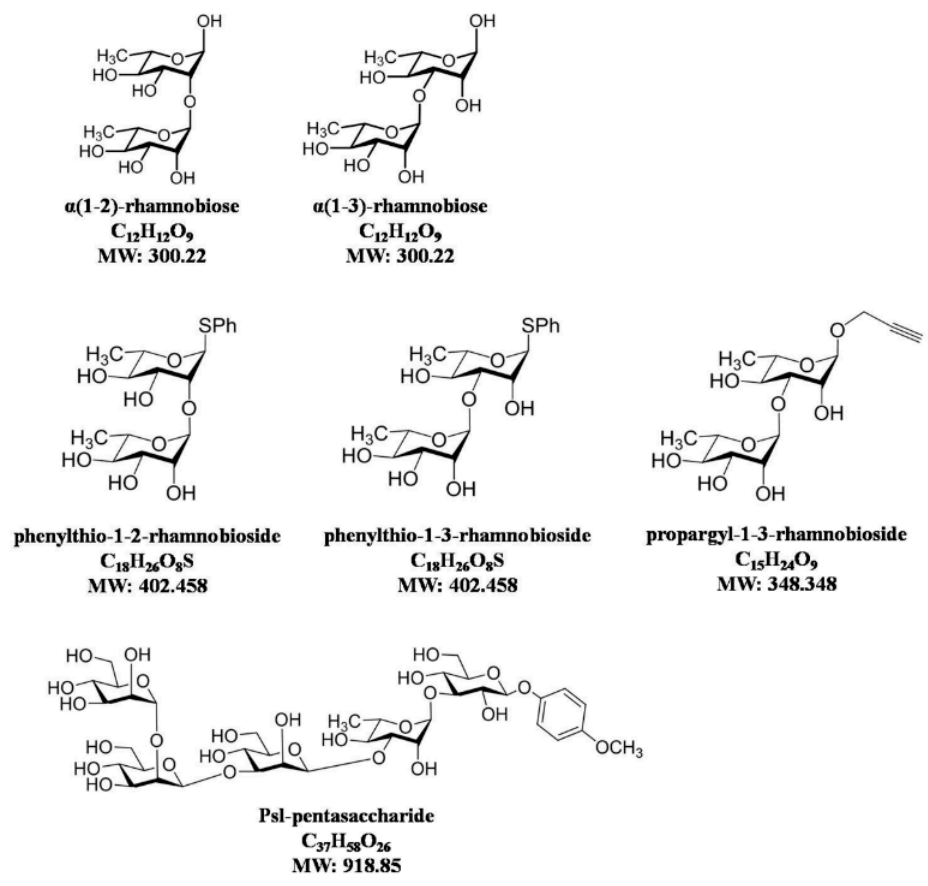

(A)

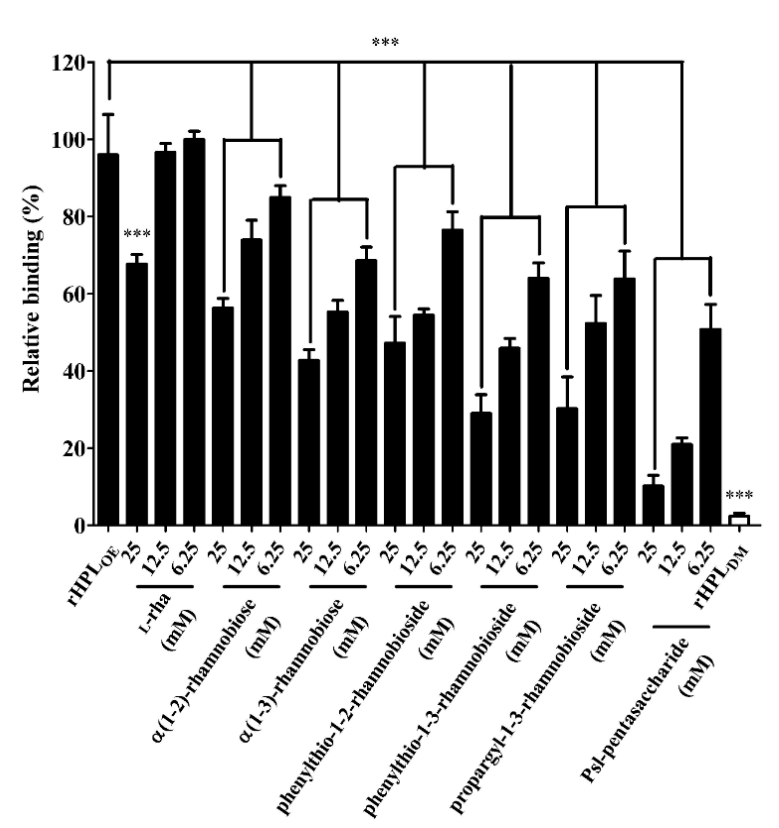

(B)

Figure 2. Structures of synthesized rhamnobioses and the rhamnose-containing Psl-pentasaccharide and inhibitory effects of thereof on the $\mathrm{rHPL}_{\mathrm{OE}}$-biofilm interaction. (A) Structures of the synthesized rhamnosyl di- and pentasaccharides: $\alpha(1-2)$-rhamnobiose, $\alpha(1-3)$-rhamnobiose, phenylthio-1-2-rhamnobioside, phenylthio-1-3-rhamnobioside, propargyl-1-3-rhamnobioside and Psl-pentasaccharide. (B) The binding activity of $\mathrm{rHPL}_{\mathrm{OE}}$ on the biofilm from Pseudomonas aeruginosa PA14 and the inhibitory effects of rhamnose or rhamnobiosides on this binding were determined by competitive ELISA. ${ }^{* *} p<0.001$ versus the $\mathrm{rHPL}_{\mathrm{OE}}$-only group. 


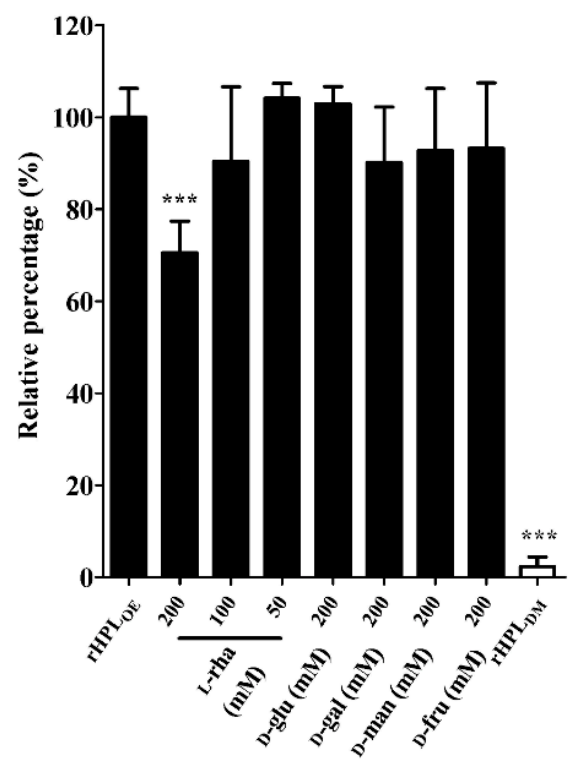

Figure 3. Inhibitory effects of monosaccharides on the $\mathrm{rHPL}_{\mathrm{OE}}$-di-rhamnolipid interaction. The binding activity of $\mathrm{rHPL}_{\mathrm{OE}}$ for di-rhamnolipid and inhibitory effects of monosaccharides on this binding was determined by competitive ELISA (competed with by L-rhamnose, D-glucose, D-galactose, D-mannose and $\mathrm{D}$-fructose). ${ }^{* * *} p<0.001$ versus the $\mathrm{HHPL}_{\mathrm{OE}}{ }^{-o n l y}$ group.

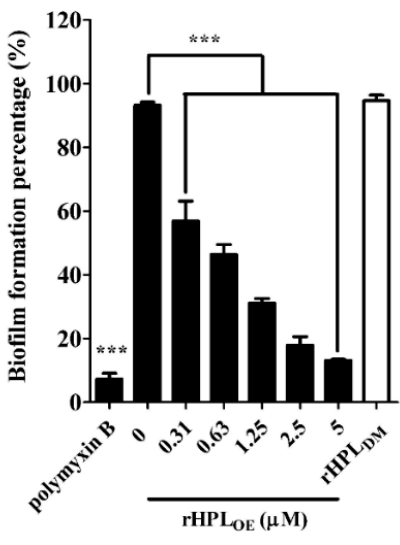

(A)

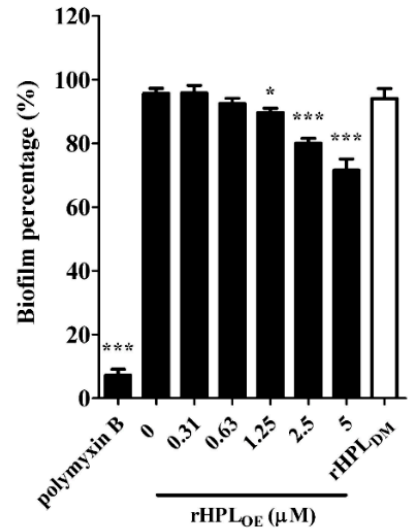

(B)

Figure 4. Inhibitory and dispersion effect on the biofilm of P. aeruginosa PA14 by $\mathrm{rHPL}$ OE. Quantification of crystal violet staining associated with (A) the biofilm of $P$. aeruginosa PA14 after treatment with $\mathrm{rHPL}_{\mathrm{OE}}$ at the indicated concentration for $24 \mathrm{~h}$ and (B) after biofilm formation for $24 \mathrm{~h}$ and treatment with $\mathrm{rHPL}_{\mathrm{OE}}$ at the indicated concentration for a further $24 \mathrm{~h}$. $\mathrm{rHPL}_{\mathrm{DM}}$ was applied as a negative control. The buffer-treated group was set as $100 \%$ (mock). ${ }^{*} p<0.05$ and ${ }^{* * *} p<0.001$ versus the buffer-treated group.

\section{6. rHPLOE Inhibited Swarming Activity and Decreased Secreted Rhamnolipids of P. aeruginosa PA14}

Swarming motility is positively correlated with the amount of extracellular rhamnolipids, leading to rapid bacterial translocation that promotes efficient colonization of bacterial cells on a surface [32]. Under optimal growth conditions, P. aeruginosa cell population would spread along a solid surface and cover a large area. If swarming were inhibited, the bacterial cell population would gather together to form a colony. The swarming area of P. aeruginosa PA14 was significantly reduced upon treatment with $\mathrm{rHPL}_{\mathrm{OE}}$ but not $\mathrm{rHPL}_{\mathrm{DM}}$ (Figure S7A). The swarming area of PA14 was reduced by $33 \%, 43 \%$, $48 \%$ and $46 \%$, respectively, upon treatment with $0.63,1.25,2.5$ and $5 \mu \mathrm{M} \mathrm{rHPL} \mathrm{OE}_{\mathrm{OE}}$ for $72 \mathrm{~h}$ (Figure S7B). Figure 5 showed that the extracellular rhamnolipid levels of PA14 $(11.7 \pm 0.4 \mu \mathrm{g} / \mathrm{mL}$ in the control 
treated with buffer) reduced by $44 \%, 50 \%, 54 \%, 64 \%$ and $59 \%$ upon treatment with $0.31,0.63,1.25,2.5$ and $5 \mu \mathrm{M} \mathrm{rHPL}_{\mathrm{OE}}$, respectively. However, the $5 \mu \mathrm{M} \mathrm{rHPL} \mathrm{DM}_{\mathrm{D}}$ treatment did not affect the extracellular rhamnolipid levels of PA14. This result was consistent with the swarming assay, indicating that the binding of $\mathrm{rHPL}_{\mathrm{OE}}$ to biofilm inhibited PA14 swarming activity by down-regulating the levels of extracellular di-rhamnolipid.

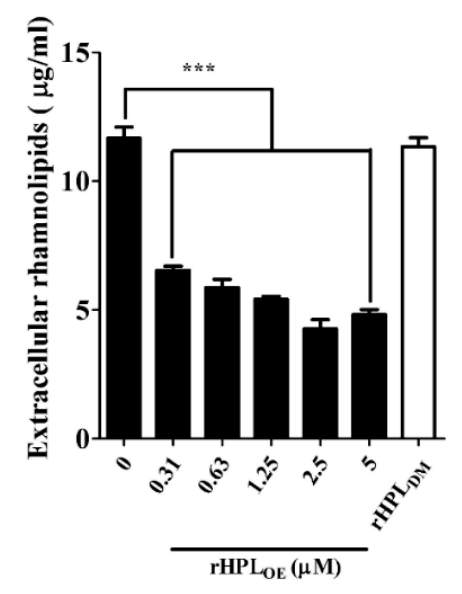

Figure 5. Down-regulation effect on extracellular rhamnolipids of P. aeruginosa PA14 by rHPL or $\mathrm{rHPL}_{\mathrm{DM}}$. Extracellular rhamnolipids of $P$. aeruginosa PA14 treated by $\mathrm{rHPL}$ OE or $\mathrm{rHPL} \mathrm{DM}_{\mathrm{DM}}$ were measured by the chloroform-methyl blue method. ${ }^{* * *} p<0.001$ versus the buffer-treated group.

\section{7. $r H P L_{O E}$ Attenuated QS-Associated Factors}

The development of biofilms appears to be regulated by the QS system. Most reagents that attenuate biofilm development work through inhibiting production of QS-factors or disrupting function of QS-factors by direct binding to QS-factors [33-35]. Among these agents, pyoverdine and pyocyanin are unique toxic molecules related to the virulence of $P$. aeruginosa PA14. To understand the attenuation mechanism of $P$. aeruginosa biofilm by $\mathrm{rHPL}_{\mathrm{OE}}$, the effect of $\mathrm{rHPL} \mathrm{LE}_{\mathrm{OE}}$ On QS-mediated azocasein-degrading protease activity and the secretion of two virulent factors, pyoverdine and pyocyanin were evaluated. Bacterial extracellular proteases degrade proteins in host cells (infected tissue), thereby facilitating bacterial invasion and growth [36]. Interestingly, bacterial protease secretion by $P$. aeruginosa $\mathrm{PA} 14$ was down-regulated by $\mathrm{rHPL}_{\mathrm{OE}}$ treatment (Figure $\mathrm{S} 8 \mathrm{~A}$ ). The azocasein-degrading assay showed that 1.25 and $2.5 \mu \mathrm{M}$ rHPL $\mathrm{OE}$ respectively decreased $16 \%$ and $12 \%$ of total proteolytic activities. Treatment with $0.31,0.63,1.25$ and $2.5 \mu \mathrm{M} \mathrm{rHPL} \mathrm{OE}_{\mathrm{E}}$ decreased the pyoverdine levels by $12 \%, 8 \%, 17 \%$ and $21 \%$, respectively (Figure S8B). Treatment with the same concentrations of $\mathrm{rHPL}_{\mathrm{OE}}$ decreased the pyocyanin levels by $41 \%, 56 \%, 45 \%$ and $40 \%$, respectively (Figure S8C).

These results indicated that the binding of $\mathrm{rHPL}_{\mathrm{OE}}$ to the biofilm down-regulated the protease activities and QS-factors (Table 1). Consistent with previous observations, $2.5 \mu \mathrm{M} \mathrm{rHPL} L_{\mathrm{DM}}$ did not show an inhibitory effect. Relatively weak inhibition of $\mathrm{rHPL}_{\mathrm{OE}}$ on protease activity and pyoverdine expression indicated that these effects might be indirect effects. The effect of $\mathrm{rHPL} \mathrm{OE}_{\mathrm{O}}$ on pyocyanin production was detectable but not concentration-dependent. A possible alternate reason for this may be that the inhibition effect of $\mathrm{rHPL}_{\mathrm{OE}}$ on pyocyanin production was compensated by other regulatory pathways.

\subsection{Combination Treatment with $r H P L_{O E}$ Improved Efficacies of Antibiotics on P. aeruginosa with Preformed Biofilms}

Since $\mathrm{rHPL}_{\mathrm{OE}}$ exhibited dispersion of P. aeruginosa PA14 biofilm, we hypothesized that $\mathrm{rHPL}$ might increase the activities of antibiotics against $P$. aeruginosa PA14 in mature biofilms. Total protein assay showed that the combination of $\mathrm{rHPL}_{\mathrm{OE}}$ with either azithromycin (hydrophobic) or cephalexin (hydrophilic) significantly attenuated the total protein levels in the biofilm. The IC50 of azithromycin 
and cephalexin to P. aeruginosa PA14 with pre-formed biofilm was $27.3 \pm 1.4$ and $27.7 \pm 0.9 \mu \mathrm{g} / \mathrm{mL}$, respectively. In the presence of $25 \mu \mathrm{g} / \mathrm{mL}$ azithromycin, in combination with $0.31,0.63,1.25$ and $2.5 \mu \mathrm{M}$ $\mathrm{rHPL}_{\mathrm{OE}}$ reduced the total protein in the biofilm by $19 \%, 21 \%, 39 \%$ and $43 \%$, respectively, compared to the antibiotic-only control (Figure 6).

Table 1. Inhibition percentage (\%) of QS-factors in $\mathrm{rHPL}_{\mathrm{OE}}$ treated P. aeruginosa PA14.

\begin{tabular}{|c|c|c|c|c|}
\hline $\mathrm{rHPL}_{\mathrm{OE}}(\mu \mathrm{M})$ & 0.31 & 0.63 & 1.25 & 2.5 \\
\hline Activities of extracellular proteases & $7 \pm 1.4$ & $4.8 \pm 0.8$ & $15.9 \pm 2.2$ & $12.4 \pm 1.4$ \\
\hline Pyoverdine & $12.3 \pm 0.2$ & $8.2 \pm 0.2$ & $16.7 \pm 0.2$ & $21.2 \pm 0.2$ \\
\hline Pyocyanin & $40.8 \pm 13.9$ & $56.1 \pm 4$ & $45.4 \pm 9.2$ & $40.5 \pm 24.2$ \\
\hline
\end{tabular}

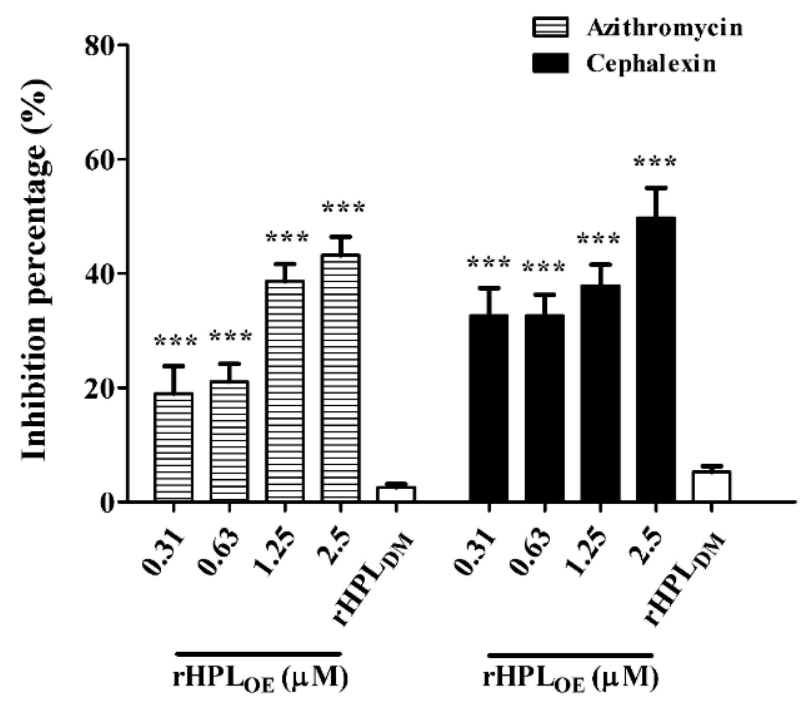

Figure 6. Synergistic effect of $\mathrm{rHPL}_{\mathrm{OE}}$ with IC50 doses of azithromycin and cephalexin on P. aeruginosa. Quantity of the percentage of biofilm total protein inhibition (with respect to the antibiotic-only control) of $P$. aeruginosa PA14. ${ }^{* * *} p<0.001$ versus the control group.

In the presence of $25 \mu \mathrm{g} / \mathrm{mL}$ cephalexin, combination treatment with the same concentrations of $\mathrm{rHPL}_{\mathrm{OE}}$ reduced the total protein in biofilms by $33 \%, 33 \%, 38 \%$ and $50 \%$, respectively, compared to the antibiotic-only control (Figure 6). This observation suggested that $\mathrm{rHPL} \mathrm{O}_{\mathrm{OE}}$ might facilitate antibiotics to kill $P$. aeruginosa PA14 by partially interfering with biofilm regulation and thus destroying the structure of the mature biofilm.

\section{9. rHPL $L_{O E}$ Inhibited Infection of P. aeruginosa in Mammalian Cells and Zebrafish Embryos}

During $P$. aeruginosa infection, rhamnolipids and pyocyanin are the important virulence factors causing cytotoxicity. Since $\mathrm{rHPL}_{\mathrm{OE}}$ inhibited rhamnolipid and pyocyanin production in P. aeruginosa PA14, we predicted that $\mathrm{rHPL}_{\mathrm{OE}}$ could also reduce P. aeruginosa PA14 infection inhuman lung cells. To evaluate this hypothesis, cell death of human lung cell line A549 by P. aeruginosa PA14 infection in the presence of $\mathrm{rHPL}_{\mathrm{OE}}$ was examined. As shown in Figure 7, the PA14-infected A549 cell death was reduced by $14 \%, 21 \%, 57 \%$ and $73 \%$ in the presence of $0.31,0.63,1.25$ and $2.5 \mu \mathrm{M} \mathrm{rHPL} \mathrm{OE}_{\mathrm{E}}$, respectively.

Regarding the negative control, $2.5 \mu \mathrm{M}$ BSA or $2.5 \mu \mathrm{M} \mathrm{rHPL}_{\mathrm{DM}}$ did not influence A549 cell death. These assays clearly demonstrated that the mortality rate of A549 cells killed by P. aeruginosa PA14 decreased due to the presence of $\mathrm{rHPL}_{\mathrm{OE}}$. Therefore, $\mathrm{rHPL}_{\mathrm{OE}}$ attenuated P. aeruginosa PA14 infection in human lung A549 cells through direct interaction between $\mathrm{rHPL}_{\mathrm{OE}}$ and rhamnose-containing bacterial compounds. 


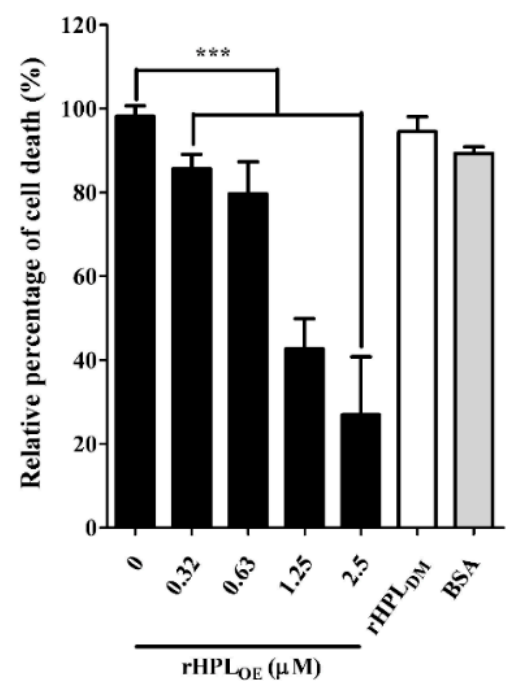

Figure 7. Inhibitory activities of $\mathrm{rHPL}_{\mathrm{OE}}$ on P. aeruginosa PA14 infection of human A549 lung cells. The percent cell death was quantified by the alamarBlue cell viability assay and normalized to cells in the absence of $\mathrm{rHPL}_{\mathrm{OE}}$, for which the cell death was set as $100 \%$. ${ }^{* * *} p<0.001$ versus the control group.

Zebrafish (Danio rerio) has become an important vertebrate animal model for many disease studies including pathogen infection [37] in recent years. Here fertilized eggs from zebrafish were used as an animal model to evaluate whether $\mathrm{rHPL}_{\mathrm{OE}}$ attenuated P. aeruginosa PA14 infection in vivo. Zebrafish embryos showed normal development in the absence of P. aeruginosa PA14, while the development of most embryos was significantly delayed or even died at $48 \mathrm{~h}$ following infection with P. aeruginosa PA14 (Figure 8).

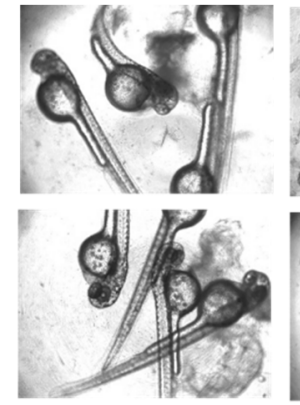

Control $40 / 44^{* 1}(90.9 \%)$

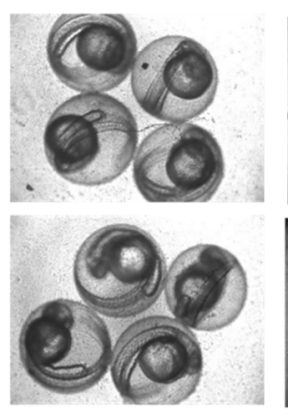

+PA14+ 2.5 $\mu \mathrm{M}$ rHPLoe 0/44 (0\%)
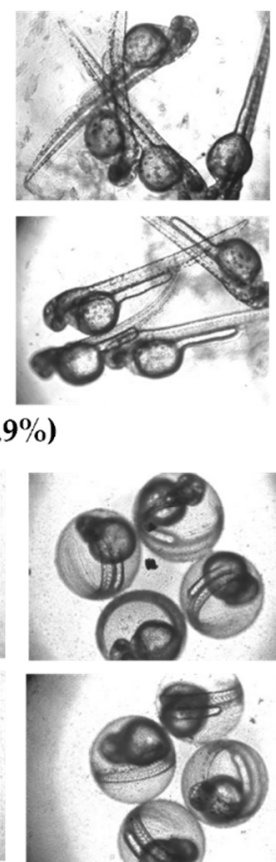

+ PA14 + 5
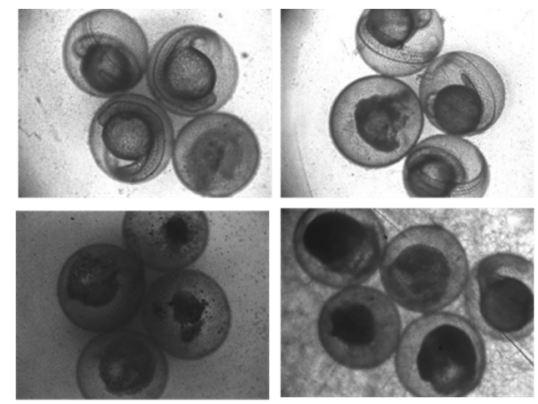

+PA14 0/45 (0\%)
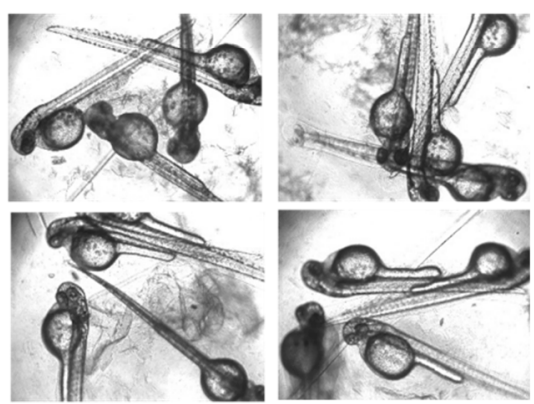

$\mu \mathrm{M}$ rHPLoe $37 / 45(82.2 \%)$

\section{*1: Larvae (48h) / fertilized egg (0h)}

Figure 8. Inhibitory activity of $\mathrm{rHPL}_{\mathrm{OE}}$ on P. aeruginosa PA14 infection of zebrafish embryos. Zebrafish embryos were infected with P. aeruginosa PA14 in the presence or absence of $\mathrm{rHPL}_{\mathrm{OE}}$ and imaged after $48 \mathrm{~h}$ of infection. All of the pictures were taken with an inverted microscope at $40 \mathrm{x}$. 
However, when P. aeruginosa PA14 was pre-incubated with $5 \mu \mathrm{M} \mathrm{rHPL} \mathrm{OE}, 82.2 \%$ of embryos developed normally as compared to control embryos showing a development rate of $90.9 \%$. Zebrafish embryos treated with $2.5 \mu \mathrm{M} \mathrm{rHPL} \mathrm{OE}$ still developed slowly, but almost all of the embryos survived. These results indicated that $\mathrm{rHPL}_{\mathrm{OE}}$ could protect zebrafish embryos from P. aeruginosa PA14 infection at concentrations higher than $2.5 \mu \mathrm{M}$.

\section{Discussion}

To study the carbohydrate components of the biofilm, carbohydrate-binding proteins, such as plant lectins, have been widely applied. Previously many different neutral carbohydrates including $\mathrm{N}$-acetyl-D-glucosamine, $\mathrm{N}$-acetyl-D-galactosamine, D-glucose and D-mannose were identified in the exopolymeric matrix of the biofilm [38]. Lectins with various specificities show an interaction with the carbohydrate components of biofilms. For example, concanavalin A from Canavalia ensiformis seeds is specific for D-glucose and D-mannose [39], and lectin from Triticum vulgaris germs is specific for $\mathrm{N}$-acetyl-D-glucosamine and sialic acid [40]. L-Rhamnose as a unique sugar in bacteria and plants is a common component of the cell wall and capsule of many pathogenic bacteria including Gram-negative P. aeruginosa [41], Salmonella typhimurium [42], Vibrio cholera [43,44] as well as Mycobacterium tuberculosis [45]. P. aeruginosa produces at least three distinct exopolysaccharides that contribute to biofilm development and architecture: Alginate, Pel and Psl [46]. Alginate consists of only uronic acids, Pel is a glucose-rich polysaccharide and Psl consists of a repeating pentasaccharide containing D-mannose, D-glucose and L-rhamnose [47]. Psl serves as a primary structural scaffold for biofilm development. In addition, Psl is involved in early stages of biofilm formation and promoting cell-to-cell interactions [48,49]. Another rhamnose-containing component in the biofilm was the QS-factor di-rhamnolipid. A mutant strain (P. aeruginosa PAO1C-rhlAB) that could not produce rhamnolipids lost its swarming activity, which agreed with our observation in $\mathrm{rHPL}_{\mathrm{OE}}$-treated PA14 [50]. rHPL $\mathrm{OE}_{\mathrm{O}}$ bound to both Psl and di-rhamnolipid through targeting rhamnose moiety and synthetic rhamnobiosides-competitive ELISA showed that $\mathrm{rHPL}_{\mathrm{OE}}$ preferred to bind with $\alpha(1-3)$-rhamnobiose rather than $\alpha(1-2)$-rhamnobiose. The linkage of the rhamnose of Psl was reported to be $\alpha(1-3)$ [47] while that of di-rhamnolipid was $\alpha(1-2)$ [51], perhaps favoring that $\mathrm{rHPL}_{\mathrm{OE}}$ binding to rhamnose component in biofilm was governed by recognition of unique structure feature of rhamnosyl moiety. Although $\mathrm{rHPL}_{\mathrm{OE}}$ binding to Psl still required more abundant glycan for detail characterization, $\mathrm{rHPL}_{\mathrm{OE}}$ binding to di-rhamnolipid down-regulated the expression of di-rhamnolipid and QS-factors of P. aeruginosa and further inhibited biofilm formation.

The most important finding of this study was that the binding of $\mathrm{rHPL}_{\mathrm{OE}}$ to the P. aeruginosa PA14 biofilm inhibited biofilm development and disrupted the mature biofilm. Our data clearly showed that $\mathrm{rHPL}_{\mathrm{OE}}$ caused these bio-effects by interacting with components in the biofilm including structural polysaccharides or di-rhamnolipid, largely due to the down-regulation of QS-factors including di-rhamnolipid, pyocyanin, pyoverdine and extracellular proteases by interrupting the functions of di-rhamnolipid.

Based on the biofilm dispersion activity of $\mathrm{rHPL}_{\mathrm{OE}}$, we proposed that $\mathrm{rHPL} \mathrm{L}_{\mathrm{OE}}$ possessed synergistic effects with antibiotics on P. aeruginosa. Two antibiotics commonly applied for treating P. aeruginosa infections, azithromycin, a hydrophobic azalide that kills bacteria by decreasing protein production and cephalexin, a hydrophilic beta-lactam that kills bacteria by inhibiting cell wall synthesis, were used in this study in combination with $\mathrm{rHPL}_{\mathrm{OE}}$. The results showed that $\mathrm{rHPL} \mathrm{OE}_{\mathrm{OE}}$ significantly improved the bactericidal activity of both antibiotics, strongly suggesting that $\mathrm{rHPL}_{\mathrm{OE}}$ was useful as a biofilm dispersion reagent for deconstructing the biofilm and improving the activities of antibiotics.

Many studies reported that $P$. aeruginosa infection could be inhibited by down-regulating QS-factors. Importantly, these anti-QS reagents (allicin, triazolyldihydrofuranone and baicalin hydrate) are effective against multidrug-resistant $P$. aeruginosa [33-35]. Studies in the past decade revealed that these anti-QS reagents also inhibited many human infections caused by biofilm-producing bacteria [52,53]. This fact is important for fighting human pathogenic bacteria, as biofilms are found to be involved in over $80 \%$ of microbial infections in humans [54]. Since $\mathrm{rHPL}_{\mathrm{OE}}$ could reduce the levels of pyoverdine and 
pyocyanin, we speculate that $\mathrm{rHPL}_{\mathrm{OE}}$ might also inhibit $P$. aeruginosa infection. It was found that rHPL $_{\mathrm{OE}}$ significantly reduced the cytotoxicity towards A549 cells and neutralized toxicity (leading to development retardation or death) of the zebrafish embryo caused by P. aeruginosa PA14.

\section{Conclusions}

Binding and down-regulation of di-rhamnolipid has not attracted much attention so far. In this study, we optimized the production of rHPL in E. coli using chaperone co-expression. $\mathrm{rHPL}_{\mathrm{OE}}$, a highly specific rhamnose binding protein, bound to not only bacterial cells and PAMPs [29] but also extracted cell-free biofilm from $P$. aeruginosa. In addition, such interaction inhibited biofilm formation and dispersed mature biofilm through down-regulating secretion of di-rhamnolipid in biofilm and further down-regulating other QS-factors including extracellular proteases, pyoverdine and pyocyanin. As a biofilm dispersion reagent, $\mathrm{rHPL}_{\mathrm{OE}}$ increased the antibiotic activity against $P$. aeruginosa PA14 with pre-formed biofilm. Therefore, $\mathrm{rHPL}_{\mathrm{OE}}$ promised to be an effective anti-biofilm agent for combination therapy. At cellular and animal levels, $\mathrm{rHPL}_{\mathrm{OE}}$ inhibited the infection and toxicity of P. aeruginosa PA14 towards human lung epithelial cells and zebrafish embryos. These results indicated that $\mathrm{rHPL}_{\mathrm{OE}}$ served as a novel anti-biofilm agent by targeting rhamnose-containing components in biofilm, which in turn linked glycan-recognition to novel anti-biofilm strategies against pathogenic bacteria.

\section{Materials and Methods}

\subsection{Bacteria Strains, Growth Medium and Plasmid}

Escherichia coli TOP10F' (Invitrogen, Waltham, MA, USA) was used as a host for vector construction and DNA manipulation. E. coli BL21(DE3) (Invitrogen, Waltham, MA, USA) was used as a host for protein expression. Pseudomonas aeruginosa PA14 (serotype O19) was kindly provided by Dr. Hwan-You Chang (Institute of Molecular Medicine, National Tsing Hua University, Hsinchu, Taiwan). The vector pET-23a (+) (Novagen, Burlington, MA, USA) with a T7 promoter was used for recombinant protein expression in E. coli cells and sequence analysis. Takara's Chaperone Plasmid Set (\#3340, TaKaRa, Shiga, Japan) was used for chaperone co-expression. All other buffers and reagents were of the highest commercial purity.

\subsection{Expression and Purification of $r H P L_{O E}$}

Chloramphenicol ( $\geq 98 \%$, \#C0378), ampicillin (96\%-102\%, \#A9393), isopropyl $\beta$-D-1-thiogalactopyranoside (IPTG, $\geq 99 \%$, \#I6758), Tris base (ACS reagent, $\geq 99.8 \%, \# 252859$ ), $\mathrm{NaCl}$ (ACS reagent, $\geq 99 \%, \# 746398$ ), imidazole ( $\geq 99 \%$, \#I5513), HCl (\#320331) and phenylmethylsulfonyl fluoride (PMSF, $\geq 99 \%$, \# 78830) was purchased from Sigma-Aldrich (St. Louis, MO, USA). Luria-Bertani (LB, \#244610) was purchased from BD (Franklin lake, NJ, USA). rHPL ${ }_{\mathrm{OE}}$ was the chaperone co-expressed product of the synthesized sequence $\left(h p l_{O E}\right)$ and the codon of $h p l_{O E}$ was optimized for E. coli expression. To generate a co-expression clone, pET23a- $h p l_{O E}$ was transformed into E. coli BL21(DE3) competent cells containing pG-KJE8 (\#3340, TaKaRa, Shiga, Japan), and transformants were selected by an LB plate with $20 \mu \mathrm{g} / \mathrm{mL}$ chloramphenicol and $50 \mu \mathrm{g} / \mathrm{mL}$ ampicillin. After induction with a final concentration of $0.1 \mathrm{mM} \mathrm{IPTG}$ at $16^{\circ} \mathrm{C}$ for $16 \mathrm{~h}$, cells were harvested by centrifugation (KUBOTA, Osaka, Japan), and the residues were suspended in equilibrium buffer (20 mM Tris- $\mathrm{HCl}$, $200 \mathrm{mM} \mathrm{NaCl}$ and $5 \mathrm{mM}$ imidazole, $\mathrm{pH}$ 7.4) supplemented with a protease inhibitor (1 mM PMSF) and disrupted by three passages through a cell homogenizer (Sonicator 3000, Misonix, Farmingdale, NY, USA) at 15,000 psi. The recombinant proteins were purified using a HisTrap ${ }^{\mathrm{TM}} \mathrm{HP}$ immobilized metal ion affinity column (\#17524701, GE Healthcare, Little Chalfont, Buckinghamshire, UK) and ÄKTA start system (GE Healthcare, Little Chalfont, Buckinghamshire, UK). Purified proteins were then concentrated and buffer-exchanged to the Tris buffer $(20 \mathrm{mM}$ Tris- $\mathrm{HCl}$ and $200 \mathrm{mM} \mathrm{NaCl}, \mathrm{pH} 7.4)$ using a $15 \mathrm{kDa}$ cut off Amicon Ultra centrifugal filter unit (\#UFC901096, Millipore, Burlington, MA, USA). 


\subsection{Biofilm Formation and Extraction}

Bacterial biofilm extraction was as described by Chibaet et al. [55]. P. aeruginosa PA14 grown on LB plates was inoculated in LB medium and incubated overnight at $37^{\circ} \mathrm{C}$ with $250 \mathrm{rpm}$ circular shaking. A portion of the overnight culture was 1000-fold diluted in $10 \mathrm{~mL}$ LB medium and incubated at $37^{\circ} \mathrm{C}$ to an $\mathrm{A} 600 \mathrm{~nm}$ of 1 . Bacterial cells with biofilm were harvested from incubated solution by centrifugation at $8000 \times g$ for $10 \mathrm{~min}$ at $25^{\circ} \mathrm{C}$ (KUBOTA, Osaka, Japan). The harvested pellet was re-suspended with $1 \mathrm{~mL}$ of $1.5 \mathrm{M} \mathrm{NaCl}$ to extract a cell-free biofilm component. The suspensions were centrifuged at $5000 \times \mathrm{g}$ for $10 \mathrm{~min}$ at $25^{\circ} \mathrm{C}$ (KUBOTA, Osaka, Japan), and the supernatants containing the biofilm fraction were collected.

\subsection{Polysaccharide Quantification in the Extracted Biofilm}

Absolute ethanol ( $\geq 99.8 \%$, \#32221), phenol (\#P1037) and sulfuric acid (95\%-98\%, \#435589) were purchased from Sigma-Aldrich (St. Louis, MO, USA). Polysaccharide in biofilm was measured as described by Tribedi and Sil [56]. Extracted biofilm solution was mixed with 2.2 volumes of chilled absolute ethanol, incubated at $-20^{\circ} \mathrm{C}$ for $1 \mathrm{~h}$ and centrifuged at $3500 \times \mathrm{g}$ for $20 \mathrm{~min}$ at $4{ }^{\circ} \mathrm{C}$ (KUBOTA, Osaka, Japan). The pellet containing exopolysaccharides was dissolved in sterile water and measured by the phenol-sulfuric acid method. Fifty microliters of re-suspended sample was mixed with $200 \mu \mathrm{L}$ phenol, and then, $750 \mu \mathrm{L}$ sulfuric acid was added. The solution was left standing for $40 \mathrm{~min}$, and vigorously shaken. After shaking, the $\mathrm{A}_{490 \mathrm{~nm}}$ was measured using a spectrophotometer (U3310, HITACHI, Tokyo, Japan), and the amount of total sugar (excluding amino sugars) was calculated with a standard curve established using glucose.

\subsection{Binding Activity of $r H P L_{O E}$ to Biofilm or Di-Rhamnolipid}

Di-rhamnolipid (95\%, \#R95DD), phosphate buffer saline (PBS, \#P3813), Tween-20 (\#P1379), L-rhamnose ( $\geq 99 \%$, \#R3875), D-glucose ( $\geq 99.5 \%$, \#G8270), D-galactose ( $\geq 99 \%$, \#G0750), D-fructose ( $\geq 99 \%$, \#F0127), D-mannose ( $\geq 99 \%$, \#M8574) and sodium alginate (\#W201502) was purchased from Sigma-Aldrich (St. Louis, MO, USA). For competitive enzyme-linked immunosorbent assays (ELISA), the extracted biofilm or prepared di-rhamnolipid solution $\left(120 \mu \mathrm{g} / \mathrm{mL}\right.$ in $\left.\mathrm{ddH}_{2} \mathrm{O}\right)$ was diluted in $10 \times$ the volume of the coating solution (\#5150-0014, SeraCare KPL, Milford, MA, USA), and $50 \mu \mathrm{L}$ of the mixture was added to each well of the 96-well microplate (\#442404, Thermo Fisher, Waltham, MA, USA) and incubated at $4{ }^{\circ} \mathrm{C}$ overnight. After blocking with a blocking reagent (\#10057177103, Roche, Basel, Switzerland) at $37^{\circ} \mathrm{C}$ for $1 \mathrm{~h}$, the plates were washed with PBST (PBS with $0.05 \%$ Tween-20) three times. To the washed wells, $25 \mu \mathrm{L}$ of $0.2 \mu \mathrm{M} \mathrm{rHPL}$ OE was mixed with $25 \mu \mathrm{L}$ of two-fold the indicated concentration of L-rhamnose, D-glucose, D-galactose, D-fructose, D-mannose or sodium alginate and the mixture was added to the wells, which were maintained at $37^{\circ} \mathrm{C}$ for $1 \mathrm{~h}$. Fifty microliters of 0.1 $\mu \mathrm{M}$ purified $\mathrm{rHPL}_{\mathrm{OE}}$ was added in parallel as a positive control, and Tris-buffer $(20 \mathrm{mM}$ Tris- $\mathrm{HCl}$ and $200 \mathrm{mM} \mathrm{NaCl}, \mathrm{pH} 7.4$ ) was added in parallel as a negative control. After washing three times with PBST, the microplates were incubated with monoclonal anti-His-tag (1:5000; \#631212, Clontech, Mountain View, CA, USA) in PBST at $37^{\circ} \mathrm{C}$ for $1 \mathrm{~h}$. Subsequently, horseradish peroxidase-conjugated anti-mouse IgG (1:5000; \#AB2338512, Jackson ImmunoResearch, West Grove, PA, USA) in PBST was added to the microplates, and after washing three times with PBST, the plates were incubated at $37^{\circ} \mathrm{C}$ for $1 \mathrm{~h}$. After being washed three times with PBST, $100 \mu \mathrm{L}$ of 3,3',5,5'-tetramethylbenzidine substrate (\#5120-0077, SeraCare KPL, Milford, MA, USA) was added to each well and incubated at $37^{\circ} \mathrm{C}$ for exactly $15 \mathrm{~min}$. Finally, the reaction was terminated by the addition of $100 \mu \mathrm{L}$ of $2 \mathrm{~N} \mathrm{H}_{2} \mathrm{SO}_{4}$. The $\mathrm{A}_{450 \mathrm{~nm}}$ was read using a microplate spectrophotometer (iMark Microplate Absorbance Reader, Bio-Rad, Hercules, CA, USA). The inhibitory constant $\left(K_{i}\right)$ was analyzed with GraphPad 5.0 software (GraphPad Software, La Jolla, CA, USA; fitted with a Binding-Competitive/Onesite-Fit Ki). 


\subsection{Anti-Biofilm Assay}

$\mathrm{KH}_{2} \mathrm{PO}_{4}\left(\geq 99 \%\right.$, \#P5655), $\mathrm{K}_{2} \mathrm{HPO}_{4}\left(\geq 99 \%\right.$, \#P3768), $\left(\mathrm{NH}_{4}\right)_{2} \mathrm{SO}_{4}\left(\geq 99 \%\right.$, \#A4418), $\mathrm{MgSO}_{4}(\geq 99.5 \%$, \#M7506), L-arginine ( $\geq 98 \%$, \#A5006), polymyxin B (meets USP testing specifications, \#P0972) and crystal violet ( $\geq 90 \%$, \#C0775) was purchased from Sigma-Aldrich (St. Louis, MO, USA). Biofilm formation was described by O'Toole [57]. Briefly, overnight culture of the P. aeruginosa PA14 in LB medium was diluted with fresh M63 medium $\left(22 \mathrm{mM} \mathrm{KH}_{2} \mathrm{PO}_{4}, 40 \mathrm{mM} \mathrm{K}_{2} \mathrm{HPO}_{4}, 15 \mathrm{mM}\left(\mathrm{NH}_{4}\right)_{2} \mathrm{SO}_{4}\right.$, $1 \mathrm{mM} \mathrm{MgSO}_{4}$ and $0.4 \%$ L-arginine). A total of $1 \times 10^{6} \mathrm{CFU} /$ well bacterial cells were then cultured with various concentrations of $\mathrm{HHPL}_{\mathrm{OE}}$ in a final volume of $100 \mu \mathrm{L}$ M63 medium onto a 96-well clear round bottom polystyrene microplate (\#3788, Thermo Fisher, Waltham, MA, USA) and incubated at $37^{\circ} \mathrm{C}$ for $24 \mathrm{~h}$ without shaking. A standard antibiotic polymyxin $\mathrm{B}(50 \mu \mathrm{g} / \mathrm{mL})$ often used to kill $P$. aeruginosa in other studies was applied as a positive control, and M63 only was used as a negative control. The suspended culture was then discarded, and the plate was washed with $\mathrm{ddH}_{2} \mathrm{O}$ twice to remove any remaining suspended cells in the microtiter wells. The biofilm was then stained with $125 \mu \mathrm{L}$ of $0.1 \%$ crystal violet for $15 \mathrm{~min}$, after which the stained biofilm was washed with $\mathrm{ddH}_{2} \mathrm{O}$ five times to remove any unbound dye. The crystal violet bound to the biofilm was solubilized with $125 \mu \mathrm{L}$ $30 \%(v / v)$ acetic acid and quantified by measuring the $\mathrm{A}_{595 \mathrm{~nm}}$ using the microplate spectrophotometer (iMark Microplate Absorbance Reader, Bio-Rad, Hercules, CA, USA). For the biofilm dispersion test, biofilm cultures were grown statically in $80 \mu \mathrm{L}$ of M63 medium for $24 \mathrm{~h}$, followed by the addition of $20 \mu \mathrm{L}$ of the indicated concentration of $\mathrm{rHPL}_{\mathrm{OE}}$ in M63 medium and incubation for an additional $24 \mathrm{~h}$. The addition of polymyxin B $(50 \mu \mathrm{g} / \mathrm{mL})$ to the culture before biofilm formation was used as a positive control.

\subsection{Swarming Motility Measurement}

The swarming motility of $P$. aeruginosa PA14 was investigated in plates containing swarming motility media (LB with $0.5 \%(\mathrm{wt})$ glucose and $0.6 \%(\mathrm{wt})$ agar). Agar was purchased from OXOID (\#LP0011, Basingstoke, Hampshire, UK). An aliquot of $2 \mu \mathrm{L}$ of motility media containing $1 \times 10^{6} \mathrm{CFU} / \mathrm{mL}$ bacterial cells was inoculated in plates with different concentrations of $\mathrm{rHPL}_{\mathrm{OE}}$. Subsequently, spots were dired for $20 \mathrm{~min}$ at room temperature and incubated at $37^{\circ} \mathrm{C}$ for $48 \mathrm{~h}$. The diameter of the circular bacterial growth was measured [50].

\subsection{Extracellular Rhamnolipid Quantification}

Methylene blue ( $\geq 82 \%$, \#M9140), sodium borate (ACS reagent, $\geq 99.5 \%$, \#S9640) and chloroform ( $\geq 99.5 \%$, \#C2432) was purchased from Sigma-Aldrich (St. Louis, MO, USA). Rhamnolipid was quantified as described by Pinzon et al. [58]. The supernatant of the anti-biofilm test was collected, and bacterial cells were removed by centrifugation (KUBOTA, Osaka, Japan). The $\mathrm{pH}$ of the cell-free supernatant was first adjusted to $2.3 \pm 0.2$ using $1 \mathrm{~N} \mathrm{HCl}$. Two hundred microliters of acidified sample was then extracted with the same volume of chloroform five times. One milliliter of the chloroform extract was carefully removed and mixed with $40 \mu \mathrm{L}$ of $0.1 \%$ methylene blue (freshly prepared and $\mathrm{pH}$ adjusted to $8.6 \pm 0.2$ with $50 \mathrm{mM}$ borate buffer) and $960 \mu \mathrm{L}$ of distilled water in a $2 \mathrm{~mL}$ tube. After being vigorously shaken for $4 \mathrm{~min}$, the samples were left to stand for $15 \mathrm{~min}$. The chloroform phase was transferred into a quartz cuvette and value of $\mathrm{A}_{638 \mathrm{~nm}}$ was measured by spectrophotometer (U3310, HITACHI, Tokyo, Japan). The values were converted to rhamnolipid concentrations using a calibration curve established by applying the same procedure to standard rhamnolipid solutions of different concentrations.

\subsection{Azocasein Degradation Assay}

The proteolytic activity was determined in the cell-free culture supernatant according to the method by Kessler et al. [59]. The amount of protease released by P. aeruginosa treated by $\mathrm{PHPL}_{\mathrm{OE}}$, the supernatant of the anti-biofilm test was collected by centrifugation (KUBOTA, Osaka, Japan). 
One hundred and fifty microliters of supernatant were added to $0.3 \%$ of $1 \mathrm{~mL}$ azocasein (\#A2765, Sigma-Aldrich St. Louis, MO, USA) in $50 \mathrm{mM}$ Tris- $\mathrm{HCl}$ (pH 7.5) and incubated at $37^{\circ} \mathrm{C}$ for $15 \mathrm{~min}$. The reaction was stopped by the addition of $0.5 \mathrm{~mL} 10 \%$ trichloroacetic acid, and the mixture was centrifuged at $8000 \times g$ for 5 min (KUBOTA, Osaka, Japan) to obtain a clear supernatant. The absorbance of the clear supernatant was then measured at $400 \mathrm{~nm}$ (U3310, HITACHI, Tokyo, Japan) [60].

\subsection{Pyoverdine Quantification Assay}

P. aeruginosa was incubated with different concentrations of $\mathrm{rHPL}_{\mathrm{OE}}$ at $37^{\circ} \mathrm{C}$ for $24 \mathrm{~h}$. Thereafter, the cultured liquid was centrifuged at $8000 \times g$ for $15 \mathrm{~min}$ (KUBOTA, Osaka, Japan), and the cell-free supernatant was used for the pyoverdine measurement. The relative concentrations of pyoverdine in all of the treated supernatants with respect to the control was measured through a fluorescence microplate spectrophotometer (Victor2, PerkinElmer, Waltham, MA, USA) at an excitation wavelength of $405 \mathrm{~nm}$ and an emission wavelength of $465 \mathrm{~nm}$ [61].

\subsection{Pyocyanin Quantification Assay}

The pyocyanin quantification assay was performed according to the method described by Essar et al. [62]. P. aeruginosa was incubated with different concentrations of $\mathrm{rHPL} \mathrm{OE}_{\mathrm{OE}}$ at $37^{\circ} \mathrm{C}$ for $24 \mathrm{~h}$, and the cell-free supernatant was collected by centrifugation (KUBOTA, Osaka, Japan). Five milliliters of the supernatant were extracted with $3 \mathrm{~mL}$ of chloroform and the chloroform layer was re-extracted with $1 \mathrm{~mL}$ of $0.2 \mathrm{~N} \mathrm{HCl}$ to produce an orange yellow to pink solution, and the chloroform phase was transferred into a quartz cuvette and value of $A_{520} \mathrm{~nm}$ was measured by a spectrophotometer (U3310, HITACHI, Tokyo, Japan).

\subsection{Synergistic Effect of $r H P L_{O E}$ with Antibiotics}

The experiment design was according to the method described by Das et al. [63]. P. aeruginosa with a mature biofilm was treated with $\mathrm{rHPL}_{\mathrm{OE}}$ in combination with either azithromycin $(\geq 95 \%$, \#75199, Sigma-Aldrich, St. Louis, MO, USA) [63] or cephalexin ( $\geq 95 \%$, \#C4895, Sigma-Aldrich, St. Louis, MO, USA) [64]. Solutions of $\mathrm{rHPL}_{\mathrm{OE}}$ in $0.3125 \mu \mathrm{M}, 0.625 \mu \mathrm{M}, 1.25 \mu \mathrm{M}$ and $2.5 \mu \mathrm{M}$ in combination with different concentrations of antibiotics were directly added to the cultured bacterial liquid with a mature biofilm and held at $37^{\circ} \mathrm{C}$ for $24 \mathrm{~h}$. The total protein and amount of biofilm were measured to validate the synergistic antibacterial effect of $\mathrm{rHPL}_{\mathrm{OE}}$ and antibiotics.

\subsection{Total Protein Concentration Measurement in the Biofilm}

Concentration of the extractable protein was determined as a measure of the P. aeruginosa biofilm population density. The microbial population density in the biofilm is assumed to be directly proportional to the extractable protein concentration [56]. After incubation, planktonic P. aeruginosa cells were removed, and adhered cells remained in the biofilm were gently washed with sterile PBS and boiled for $30 \mathrm{~min}$ in $5 \mathrm{~mL}$ of $0.5 \mathrm{~N} \mathrm{NaOH}$ (ACS reagent, $\geq 97 \%$, \#221465, Sigma-Aldrich, St. Louis, $\mathrm{MO}, \mathrm{USA}$ ) to extract the protein. After that, the suspension was centrifuged at $8000 \times g$ for $5 \mathrm{~min}$ (KUBOTA, Osaka, Japan), and the resulting clear supernatant was collected. The supernatant protein concentration was then measured by the bicinchoninic acid (BCA) protein assay kit (\#23225, Thermo Fisher, Waltham, MA, USA).

\subsection{Anti-A549 Infection Assay}

The Roswell Park Memorial Institute (RPMI)-1640 medium (\#10-040 CMS) and AntibioticsAntimycotic solution (PSA, \#30-004-CIS) was purchased from Corning (Corning, NY, USA). Characterized fetal bovine serum (FBS, \#SH30071) was purchased from HyClone Laboratory (Logan, UT, USA). The A549 infection model was modified from method described by Chi [65]. A549 cells (ATCC ${ }^{\circledR}$ number: CCL-185 ${ }^{\mathrm{TM}}, \mathrm{BCRC}, \mathrm{Hsinchu}$, Taiwan), adenocarcinomic human lung cells, were 
seeded in 96-well tissue culture plates at $2 \times 10^{4}$ containing $100 \mu \mathrm{L}$ of RPMI- 1640 medium supplemented with $10 \%(v / v)$ fetal FBS and $1 \%(v / v)$ PSA and allowed to grow at $37^{\circ} \mathrm{C}$ for 16 to $18 \mathrm{~h}$. Culture supernatants were removed, the monolayer was washed once with PBS buffer, and then $50 \mu \mathrm{L}$ of serum-free RPMI-1640 containing two times the indicated concentration of rHPL $\mathrm{OE}_{\mathrm{OE}}$ was added to cells and incubated for $30 \mathrm{~min}$, followed by inoculation with P. aeruginosa PA14. RPMI-1640 with $5 \mu \mathrm{M}$ BSA or $\mathrm{rHPL}_{\mathrm{DM}}$ was used as negative controls. For inoculation, the fresh bacterial cells cultured in LB broth were washed with PBS, re-suspended and diluted in RPMI-1640 medium to a concentration of $1 \times 10^{8} \mathrm{CFU} / \mathrm{mL}$. Thereafter, $50 \mu \mathrm{L}$ of the bacterial dilution was applied to the $\mathrm{rHPL}_{\mathrm{OE}}$-treated A549 cells at a multiplicity of infection (MOI) of 50 (i.e., $1 \times 10^{6} \mathrm{CFU} / 50 \mu \mathrm{L} /$ well). The blank group was A549 cells treated by $2.5 \mu \mathrm{M} \mathrm{rHPL} O E$ without bacterial infection. After infection for $16 \mathrm{~h}$ at $37^{\circ} \mathrm{C}$, the A549 cell viability was determined by the AlamarBlue cell viability assay (BUF012B, Bio-Rad, Hercules, CA, USA). It should be noted that $50 \mu \mathrm{g} / \mathrm{mL}$ polymyxin B should be added to alamarBlue reagent to prevent a survival signal from residual bacteria. The level of viability, expressed as a percentage, was calculated as follows: $\%$ viability $=[\mathrm{OD}$ of assay cells/OD of control cells $] \times 100$.

\subsection{Anti-Zebrafish Infection Assay}

Zebrafish embryos were purchased from Gendanio Biotech Inc. (New Taipei City, Taiwan). Healthy, transparent and regular embryos were selected and aliquoted into 96-well plates with four embryos per well, followed by incubation at $28^{\circ} \mathrm{C}$ in $100 \mu \mathrm{L}$ embryo water. Thereafter, $100 \mu \mathrm{L}$ of P. aeruginosa $\left(1 \times 10^{8} \mathrm{CFU} / \mathrm{mL}\right)$ pre-incubated with $5 \mathrm{mM} \mathrm{rHPL}_{\mathrm{OE}}$ for $1 \mathrm{~h}$ was added to the embryos at $24 \mathrm{~h}$ post-fertilization (hpf). The zebrafish embryos were further incubated at $28{ }^{\circ} \mathrm{C}$, and the development of each embryo in $24 \mathrm{~h}$ and $48 \mathrm{~h}$ was observed using an inverted microscope (TS100, NIKON, Tokyo, Japan) equipped with a digital camera. The number of larva at $48 \mathrm{~h}$ in each group was counted, and the rate of successful development was calculated. All zebrafish related experiments were conducted in accordance with the ethical guidelines of Council of Agriculture, Executive Yuan and Ministry of Science and Technology.

\subsection{Statistical Analyses}

All statistical analyses were carried out using GraphPad Prism version 5.01 for Windows (GraphPad Software, La Jolla, CA, USA). Each value was the average of three measurements, where the presented data is the mean $\pm \mathrm{SD}$. All means were compared by one-way ANOVA.

Supplementary Materials: The following are available online at http://www.mdpi.com/1660-3397/17/6/355/s1. The supplementary materials contained: 1 . Table S1 FPLC purification scheme of rHPL $\mathrm{OE}, 2$. Figure S1. Bacterial cell or PAMP binding activity of $\mathrm{rHPL}_{\mathrm{OE}}$ and $\mathrm{rHPL}_{\mathrm{DM}}$, 3. Figure S2. Purification and characterization of $\mathrm{rHPL} \mathrm{LE}_{\mathrm{OE}}$ with HisTrap ${ }^{\mathrm{TM}} \mathrm{HP}$ immobilized metal ion affinity chromatography, 4. Figure S3. Secondary structure analysis of $\mathrm{rHPL}_{\mathrm{OE}}, \mathrm{rHPL}_{\mathrm{DM}}$ and $\mathrm{rHPL}$ using circular dichroism (CD), 5. Figure S4. Structure and NMR spectra $\left({ }^{1} \mathrm{H}\right.$ and $\left.{ }^{13} \mathrm{C}\right)$ of pehnylthio-1-2-rhamnobioside, 6 . Figure S5. Structure and NMR spectra $\left({ }^{1} \mathrm{H}\right.$ and $\left.{ }^{13} \mathrm{C}\right)$ of phenylthio-1-3-rhamnobioside, 7. Figure S6. Structure and NMR spectra $\left({ }^{1} \mathrm{H}\right.$ and $\left.{ }^{13} \mathrm{C}\right)$ of Psl-pentasaccharide. 4-Methoxyphenyl $\alpha$-D-mannopyranosyl$(1 \rightarrow 2)-\beta$-D-mannopyranosyl-( $1 \rightarrow 3)-\beta$-D-mannopyranosyl-( $1 \rightarrow 3)-\alpha$-L-rhamnopyranosyl-( $1 \rightarrow 3)$ - $\beta$-D-glucopyranoside, 8. Figure S7. Inhibitory effect on the swarming motility of P. aeruginosa PA14 by rHPL $\mathrm{OE}$ or $\mathrm{rHPL} \mathrm{DM}_{\mathrm{D}}, 9$. Figure S8. Down-regulation effect on the extracellular protease activities or QS-factors of P. aeruginosa PA14 by rHPL $\mathrm{OE}_{\text {. }}$

Author Contributions: Conceptualization, T.-K.F. S.-K.N. and Y.-C.L.; Methodology, T.-K.F., S.-K.N, A.B., C.-Y.L., C.-H.C, C.-L.C and Y.-C.L.; Resources, F.D., M.H. and A.B.; Experiments were carried out by T.-K.F., S.-K.N., F.D. and Y.-E.C.; Writing-original draft preparation, T.-K.F.; writing-review and editing, S.-K.N., A.B., C.-H.C, C.-L.C., C.-Y.L., Y.-C.L. and M.D.-T.C.; Funding acquisition, project administration and supervision, M.D.-T.C. and Y.-C.L.; All authors read and approved the final manuscript.

Funding: This study was funded by Ministry of Science and Technology (MOST) grants (MOST 103-2627-M-007-006 and MOST 107-0210-01-19-04) to Dr. Margaret Dah-Tsyr Chang, as well as by Simpson Biotech Co., Ltd. (Taiwan). The research was also supported by the EU and co-financed by the European Regional Development Fund under the projects GINOP-2.3.2-15-2016-00008 (A. B.) and by the ÚNKP-18-3 New National Excellence Program of the Ministry of Human Capacities of Hungary (F. D.).

Acknowledgments: We thank Hwan-You Chang for providing P. aeruginosa PA14. We also thank Yung-Jen Chuang for directing the experiments about zebrafish, as well as for providing valuable comments. 
Conflicts of Interest: The authors declare no conflict of interest. The funders (Simpson Biotech Co., Ltd.) had no role in the design of the study; in the collection, analyses, or interpretation of data; in the writing of the manuscript, or in the decision to publish the results.

\section{References}

1. Cegelski, L.; Marshall, G.R.; Eldridge, G.R.; Hultgren, S.J. The biology and future prospects of antivirulence therapies. Nat. Rev. Microbiol. 2008, 6, 17-27. [CrossRef] [PubMed]

2. Kalia, V.C.; Purohit, H.J. Quenching the quorum sensing system: Potential antibacterial drug targets. Crit. Rev. Microbiol. 2011, 37, 121-140. [CrossRef] [PubMed]

3. Sharma, G.; Rao, S.; Bansal, A.; Dang, S.; Gupta, S.; Gabrani, R. Pseudomonas aeruginosa biofilm: Potential therapeutic targets. Biologicals 2014, 42,1-7. [CrossRef] [PubMed]

4. Deep, A.; Chaudhary, U.; Gupta, V. Quorum sensing and bacterial pathogenicity: From molecules to disease. J. Lab. Physicians 2011, 3, 4-11. [CrossRef] [PubMed]

5. Bjarnsholt, T. The role of bacterial biofilms in chronic infections. APMIS. Suppl. 2013, 1-51. [CrossRef]

6. Wiehlmann, L.; Wagner, G.; Cramer, N.; Siebert, B.; Gudowius, P.; Morales, G.; Kohler, T.; Van Delden, C.; Weinel, C.; Slickers, P.; et al. Population structure of Pseudomonas aeruginosa. Proc. Nat. Acad. Sci. USA 2007, 104, 8101-8106. [CrossRef]

7. He, J.; Baldini, R.L.; Deziel, E.; Saucier, M.; Zhang, Q.; Liberati, N.T.; Lee, D.; Urbach, J.; Goodman, H.M.; Rahme, L.G. The broad host range pathogen Pseudomonas aeruginosa strain PA14 carries two pathogenicity islands harboring plant and animal virulence genes. Proc. Nat. Acad. Sci. USA 2004, 101, 2530-2535. [CrossRef]

8. Mikkelsen, H.; Ball, G.; Giraud, C.; Filloux, A. Expression of Pseudomonas aeruginosa CupD fimbrial genes is antagonistically controlled by RcsB and the EAL-containing PvrR response regulators. PLoS ONE 2009, 4, e6018. [CrossRef]

9. Watnick, P.; Kolter, R. Biofilm, city of microbes. J. Bacteriol. 2000, 182, 2675-2679. [CrossRef]

10. Jakobsen, T.H.; Bjarnsholt, T.; Jensen, P.O.; Givskov, M.; Hoiby, N. Targeting quorum sensing in Pseudomonas aeruginosa biofilms: Current and emerging inhibitors. Future Microbiol. 2013, 8, 901-921. [CrossRef]

11. Gambello, M.J.; Iglewski, B.H. Cloning and characterization of the Pseudomonas aeruginosa lasR gene, a transcriptional activator of elastase expression. J. Bacteriol. 1991, 173, 3000-3009. [CrossRef] [PubMed]

12. Ochsner, U.A.; Koch, A.K.; Fiechter, A.; Reiser, J. Isolation and characterization of a regulatory gene affecting rhamnolipid biosurfactant synthesis in Pseudomonas aeruginosa. J. Bacteriol. 1994, 176, 2044-2054. [CrossRef] [PubMed]

13. Davies, D.G.; Parsek, M.R.; Pearson, J.P.; Iglewski, B.H.; Costerton, J.W.; Greenberg, E.P. The involvement of cell-to-cell signals in the development of a bacterial biofilm. Science 1998, 280, 295-298. [CrossRef] [PubMed]

14. Pearson, J.P.; Pesci, E.C.; Iglewski, B.H. Roles of Pseudomonas aeruginosa las and rhl quorum-sensing systems in control of elastase and rhamnolipid biosynthesis genes. J. Bacteriol. 1997, 179, 5756-5767. [CrossRef]

15. Rasamiravaka, T.; Labtani, Q.; Duez, P.; El Jaziri, M. The formation of biofilms by Pseudomonas aeruginosa: A review of the natural and synthetic compounds interfering with control mechanisms. BioMed Res. Int. 2015, 2015, 759348. [CrossRef] [PubMed]

16. Smith, K.M.; Bu, Y.; Suga, H. Library screening for synthetic agonists and antagonists of a Pseudomonas aeruginosa autoinducer. Chem. Biol. 2003, 10, 563-571. [CrossRef]

17. Papa, R.; Selan, L.; Parrilli, E.; Tilotta, M.; Sannino, F.; Feller, G.; Tutino, M.L.; Artini, M. Anti-biofilm activities from marine cold adapted bacteria against staphylococci and Pseudomonas aeruginosa. Front. Microbiol. 2015, 6, 1333. [CrossRef] [PubMed]

18. Artini, M.; Patsilinakos, A.; Papa, R.; Bozovic, M.; Sabatino, M.; Garzoli, S.; Vrenna, G.; Tilotta, M.; Pepi, F.; Ragno, R.; et al. Antimicrobial and antibiofilm activity and machine learning classification analysis of essential oils from different mediterranean plants against Pseudomonas aeruginosa. Molecules 2018, $23,482$. [CrossRef]

19. Wu, S.; Liu, G.; Jin, W.; Xiu, P.; Sun, C. Antibiofilm and anti-infection of a marine bacterial exopolysaccharide against Pseudomonas aeruginosa. Front. Microbiol. 2016, 7, 102. [CrossRef]

20. Pamp, S.J.; Tolker-Nielsen, T. Multiple roles of biosurfactants in structural biofilm development by Pseudomonas aeruginosa. J. Bacteriol. 2007, 189, 2531-2539. [CrossRef] [PubMed] 
21. Davey, M.E.; Caiazza, N.C.; O'Toole, G.A. Rhamnolipid surfactant production affects biofilm architecture in Pseudomonas aeruginosa PAO1. J. Bacteriol. 2003, 185, 1027-1036. [CrossRef] [PubMed]

22. Glick, R.; Gilmour, C.; Tremblay, J.; Satanower, S.; Avidan, O.; Deziel, E.; Greenberg, E.P.; Poole, K.; Banin, E. Increase in rhamnolipid synthesis under iron-limiting conditions influences surface motility and biofilm formation in Pseudomonas aeruginosa. J. Bacteriol. 2010, 192, 2973-2980. [CrossRef] [PubMed]

23. Naganuma, T.; Ogawa, T.; Hirabayashi, J.; Kasai, K.; Kamiya, H.; Muramoto, K. Isolation, characterization and molecular evolution of a novel pearl shell lectin from a marine bivalve, Pteria penguin. Mol. Divers. 2006, 10, 607-618. [CrossRef] [PubMed]

24. Tateno, H. SUEL-related lectins, a lectin family widely distributed throughout organisms. Biosci. Biotechnol. Biochem. 2010, 74, 1141-1144. [CrossRef] [PubMed]

25. Tateno,H.; Yamaguchi, T.; Ogawa, T.; Muramoto, K.; Watanabe, T.; Kamiya,H.; Saneyoshi, M. Immunohistochemical localization of rhamnose-binding lectins in the steelhead trout (Oncorhynchus mykiss). Dev. Comp. Immunol. 2002, 26, 543-550. [CrossRef]

26. Tateno, H.; Ogawa, T.; Muramoto, K.; Kamiya, H.; Saneyoshi, M. Rhamnose-binding lectins from steelhead trout (Oncorhynchus mykiss) eggs recognize bacterial lipopolysaccharides and lipoteichoic acid. Biosci. Biotechnol. Biochem. 2002, 66, 604-612. [CrossRef] [PubMed]

27. Booy, A.; Haddow, J.D.; Olafson, R.W. Isolation of the salmonid rhamnose-binding lectin STL2 from spores of the microsporidian fish parasite Loma salmonae. J. Fish Dis. 2005, 28, 455-462. [CrossRef]

28. Sugawara, S.; Hosono, M.; Ogawa, Y.; Takayanagi, M.; Nitta, K. Catfish egg lectin causes rapid activation of multidrug resistance 1 P-glycoprotein as a lipid translocase. Biol. Pharm. Bull. 2005, 28, 434-441. [CrossRef]

29. Ng, S.K.; Huang, Y.T.; Lee, Y.C.; Low, E.L.; Chiu, C.H.; Chen, S.L.; Mao, L.C.; Chang, M.D. A recombinant horseshoe crab plasma lectin recognizes specific pathogen-associated molecular patterns of bacteria through rhamnose. PLoS ONE 2014, 9, e115296. [CrossRef]

30. Herczeg, M.; Mezo, E.; Molnar, N.; Ng, S.K.; Lee, Y.C.; Dah-Tsyr Chang, M.; Borbas, A. Inhibitory effect of multivalent rhamnobiosides on recombinant horseshoe crab plasma lectin interactions with Pseudomonas aeruginosa PAO1. Chem. Asian J. 2016, 11, 3398-3413. [CrossRef]

31. Mah, T.F.; O'Toole, G.A. Mechanisms of biofilm resistance to antimicrobial agents. Trends Microbiol. 2001, 9, 34-39. [CrossRef]

32. Kumar, L.; Chhibber, S.; Harjai, K. Zingerone inhibit biofilm formation and improve antibiofilm efficacy of ciprofloxacin against Pseudomonas aeruginosa PAO1. Fitoterapia 2013, 90, 73-78. [CrossRef] [PubMed]

33. Hentzer, M.; Wu, H.; Andersen, J.B.; Riedel, K.; Rasmussen, T.B.; Bagge, N.; Kumar, N.; Schembri, M.A.; Song, Z.; Kristoffersen, P.; et al. Attenuation of Pseudomonas aeruginosa virulence by quorum sensing inhibitors. EMBO J. 2003, 22, 3803-3815. [CrossRef] [PubMed]

34. Kim, B.; Park, J.S.; Choi, H.Y.; Yoon, S.S.; Kim, W.G. Terrein is an inhibitor of quorum sensing and c-di-GMP in Pseudomonas aeruginosa: A connection between quorum sensing and c-di-GMP. Sci. Rep. 2018, 8, 8617. [CrossRef] [PubMed]

35. Subhadra, B.; Kim, D.H.; Woo, K.; Surendran, S.; Choi, C.H. Control of biofilm formation in healthcare: Recent advances exploiting quorum-sensing interference strategies and multidrug efflux pump inhibitors. Materials 2018, 11, 1676. [CrossRef] [PubMed]

36. Musthafa, K.S.; Saroja, V.; Pandian, S.K.; Ravi, A.V. Antipathogenic potential of marine Bacillus sp. SS4 on $\mathrm{N}$-acyl-homoserine-lactone-mediated virulence factors production in Pseudomonas aeruginosa (PAO1). J. Biosci. 2011, 36, 55-67. [CrossRef]

37. Goldsmith, J.R.; Jobin, C. Think small: Zebrafish as a model system of human pathology. J. Biomed. Biotechnol. 2012, 2012, 817341. [CrossRef] [PubMed]

38. Purish, L.M.; Asaulenko, L.G.; Abdulina, D.R.; Voitchuk, S.I.; Iutinskaia, G.A. Lectin-binding analysis of the biofilm exopolymeric matrix carbohydrate composition of corrosion-aggressive bacteria. Prikl. Biokhim. Mikrobiol. 2013, 49, 450-456.

39. Sumner, J.B.; Gralen, N.; Eriksson-Quensel, I.B. The molecular weights of urease, canavalin, concanavalin a and concanavalin B. Science 1938, 87, 395-396. [CrossRef]

40. Wu, A.M.; Wu, J.H.; Song, S.C.; Tsai, M.S.; Herp, A. Studies on the binding of wheat germ agglutinin (Triticum vulgaris) to O-glycans. FEBS Lett. 1998, 440, 315-319. [CrossRef]

41. Burrows, L.L.; Charter, D.F.; Lam, J.S. Molecular characterization of the Pseudomonas aeruginosa serotype O5 (PAO1) B-band lipopolysaccharide gene cluster. Mol. Microbiol 1996, 22, 481-495. [CrossRef] [PubMed] 
42. Li, Q.; Reeves, P.R. Genetic variation of dTDP-L-rhamnose pathway genes in Salmonella enterica. Microbiology 2000, 146, 2291-2307. [CrossRef] [PubMed]

43. Chiang, S.L.; Mekalanos, J.J. rfb mutations in Vibrio cholerae do not affect surface production of toxin-coregulated pili but still inhibit intestinal colonization. Infect. Immun. 1999, 67, 976-980. [PubMed]

44. Yamashita, Y.; Tomihisa, K.; Nakano, Y.; Shimazaki, Y.; Oho, T.; Koga, T. Recombination between gtfB and $g t f C$ is required for survival of a dTDP-rhamnose synthesis-deficient mutant of Streptococcus mutans in the presence of sucrose. Infect. Immun. 1999, 67, 3693-3697. [PubMed]

45. Ma, Y.; Stern, R.J.; Scherman, M.S.; Vissa, V.D.; Yan, W.; Jones, V.C.; Zhang, F.; Franzblau, S.G.; Lewis, W.H.; McNeil, M.R. Drug targeting Mycobacterium tuberculosis cell wall synthesis: Genetics of dTDP-rhamnose synthetic enzymes and development of a microtiter plate-based screen for inhibitors of conversion of dTDP-glucose to dTDP-rhamnose. Antimicrob. Agents Chemother. 2001, 45, 1407-1416. [CrossRef] [PubMed]

46. Ryder, C.; Byrd, M.; Wozniak, D.J. Role of polysaccharides in Pseudomonas aeruginosa biofilm development. Curr. Opin. Microbiol. 2007, 10, 644-648. [CrossRef] [PubMed]

47. Byrd, M.S.; Sadovskaya, I.; Vinogradov, E.; Lu, H.; Sprinkle, A.B.; Richardson, S.H.; Ma, L.; Ralston, B.; Parsek, M.R.; Anderson, E.M.; et al. Genetic and biochemical analyses of the Pseudomonas aeruginosa Psl exopolysaccharide reveal overlapping roles for polysaccharide synthesis enzymes in Psl and LPS production. Mol. Microbiol 2009, 73, 622-638. [CrossRef]

48. Ma, L.; Conover, M.; Lu, H.; Parsek, M.R.; Bayles, K.; Wozniak, D.J. Assembly and development of the Pseudomonas aeruginosa biofilm matrix. PLoS Pathog. 2009, 5, e1000354. [CrossRef]

49. Colvin, K.M.; Gordon, V.D.; Murakami, K.; Borlee, B.R.; Wozniak, D.J.; Wong, G.C.; Parsek, M.R. The pel polysaccharide can serve a structural and protective role in the biofilm matrix of Pseudomonas aeruginosa. PLoS Pathog. 2011, 7, e1001264. [CrossRef]

50. Morris, J.D.; Hewitt, J.L.; Wolfe, L.G.; Kamatkar, N.G.; Chapman, S.M.; Diener, J.M.; Courtney, A.J.; Leevy, W.M.; Shrout, J.D. Imaging and analysis of Pseudomonas aeruginosa swarming and rhamnolipid production. Appl. Environ. Microbiol. 2011, 77, 8310-8317. [CrossRef]

51. Abdel-Mawgoud, A.M.; Lepine, F.; Deziel, E. Rhamnolipids: Diversity of structures, microbial origins and roles. Appl. Environ. Microbiol. 2010, 86, 1323-1336. [CrossRef] [PubMed]

52. Manner, S.; Fallarero, A. Screening of natural product derivatives identifies two structurally related flavonoids as potent quorum sensing inhibitors against gram-negative bacteria. Int. J. Mol. Sci. 2018, 19, 1346. [CrossRef] [PubMed]

53. Tshikantwa, T.S.; Ullah, M.W.; He, F.; Yang, G. Current trends and potential applications of microbial interactions for human welfare. Front. Microbiol. 2018, 9, 1156. [CrossRef] [PubMed]

54. Biel, M.A. Photodynamic therapy of bacterial and fungal biofilm infections. Methods Mol. Biol. 2010, 635, 175-194. [CrossRef] [PubMed]

55. Chiba, A.; Sugimoto, S.; Sato, F.; Hori, S.; Mizunoe, Y. A refined technique for extraction of extracellular matrices from bacterial biofilms and its applicability. Microb. Biotechnol. 2015, 8, 392-403. [CrossRef] [PubMed]

56. Tribedi, P.; Sil, A.K. Cell surface hydrophobicity: A key component in the degradation of polyethylene succinate by Pseudomonas sp. AKS2. J. Appl. Microbiol. 2014, 116, 295-303. [CrossRef] [PubMed]

57. O’Toole, G.A. Microtiter dish biofilm formation assay. J. Vis. Exp. 2011. [CrossRef] [PubMed]

58. Pinzon, N.M.; Ju, L.K. Analysis of rhamnolipid biosurfactants by methylene blue complexation. Appl. Microbiol. Biotechnol. 2009, 82, 975-981. [CrossRef] [PubMed]

59. Kessler, E.; Safrin, M.; Olson, J.C.; Ohman, D.E. Secreted LasA of Pseudomonas aeruginosa is a staphylolytic protease. J. Biol. Chem. 1993, 268, 7503-7508.

60. Wiegand, I.; Hilpert, K.; Hancock, R.E. Agar and broth dilution methods to determine the minimal inhibitory concentration (MIC) of antimicrobial substances. Nat. Protoc. 2008, 3, 163-175. [CrossRef]

61. Adonizio, A.; Kong, K.F.; Mathee, K. Inhibition of quorum sensing-controlled virulence factor production in Pseudomonas aeruginosa by South Florida plant extracts. Antimicrob. Agents Chemother. 2008, 52, 198-203. [CrossRef] [PubMed]

62. Essar, D.W.; Eberly, L.; Hadero, A.; Crawford, I.P. Identification and characterization of genes for a second anthranilate synthase in Pseudomonas aeruginosa: Interchangeability of the two anthranilate synthases and evolutionary implications. J. Bacteriol. 1990, 172, 884-900. [CrossRef] 
63. Das, M.C.; Sandhu, P.; Gupta, P.; Rudrapaul, P.; De, U.C.; Tribedi, P.; Akhter, Y.; Bhattacharjee, S. Attenuation of Pseudomonas aeruginosa biofilm formation by Vitexin: A combinatorial study with azithromycin and gentamicin. Sci. Rep. 2016, 6, 23347. [CrossRef] [PubMed]

64. Bassetti, M.; Vena, A.; Croxatto, A.; Righi, E.; Guery, B. How to manage Pseudomonas aeruginosa infections. Drugs Context 2018, 7, 212527. [CrossRef] [PubMed]

65. Chi, E.; Mehl, T.; Nunn, D.; Lory, S. Interaction of Pseudomonas aeruginosa with A549 pneumocyte cells. Infect. Immun. 1991, 59, 822-828.

(C) 2019 by the authors. Licensee MDPI, Basel, Switzerland. This article is an open access article distributed under the terms and conditions of the Creative Commons Attribution (CC BY) license (http://creativecommons.org/licenses/by/4.0/). 